\title{
CARBOHYDRATE MEASUVEMENTS ON FOUR BRANDS OF COCONUT WATER
}

\author{
HERNETE DE JESUS SANTOS OLIVEIRA ${ }^{1}$ \\ CELESTE MARIA PATTO DE ABREU ${ }^{2}$ \\ CUSTÓDIO DONIZETE DOS SANTOS ${ }^{2}$ \\ MARIA DAS GRAÇAS CARDOSO ${ }^{3}$ \\ JULIANA ÉRICA CARVALHO TEIXEIRA ${ }^{4}$ \\ NILSON CÉSAR CASTANHEIRA GUIMARÃES ${ }^{5}$
}

\begin{abstract}
Utilization of water from dry coconuts to produce long-life coconut water, using a $20 \%$ mixture of green coconut water in order to reach the quality standard demanded by Brazilian customers, has been done since 2000. That is one more alternative for the by products from Cocos nucifera L. processing industries, introducing marketing advantages like: better storage, longer shelf life, transportation, and visual quality to the customer. Packed with ultrasonic Swedish technology, coconut water has been already commercialized in establishments in Southeastern Brazil. In this work, carbohydrate contents of four
\end{abstract}

coconut water brands and the natural coconut water were comparatively analyzed, and the contents of fructose, glucose, sucrose, total sugars, and reducing sugars were determined. The coconut water used in this research was bought in Lavras, Minas Gerais St., as well as the green coconut water, which was used as a control. The statistical design was completely randomized, and the treatments were five brands with five replicates. The analyses were performed in the Biochemistry laboratory, of UFLA's Chemistry Department. Two out of four commercial brands, brands B and D, did not achieve the quality standards cited in the literature.

INDEX TERMS: Cocos nucifera L., carbohydrates, fructose, sucrose, glucose.

\section{TEORES DE GLICÍDIOS EM QUATRO MARCAS DE ÁGUA DE COCO}

\begin{abstract}
RESUMO - O aproveitamento da água de coco seco, para a produção de água de coco longa-vida com uma mistura de $20 \%$ de água de coco verde, para atingir o padrão de qualidade exigido pelo consumidor brasileiro, vem sendo utilizado desde 2000. Trata-se de mais uma alternativa para as indústrias de processamento dos produtos derivados dos frutos de Cocos nucifera L., apresentando vantagens mercadológicas como: facilidade de estocagem, maior vida de prateleira, transporte e exposição ao consumidor. Embalada com tecnologia sueca ultra-sônica, já está sendo comercializada em estabelecimentos de gêneros alimentícios também na Região Sudeste do Brasil. Com este trabalho, analisou-se
\end{abstract}

TERMOS PARA INDEXAÇÃO: Água de coco, carboidratos, frutose, glicose, sacarose.

1. Bióloga, mestre em Agrobioquímica do Departamento de Química, UNIVERSIDADE FEDERAL DE LAVRAS/ UFLA, Caixa Postal 37, 37200-000 - Lavras, MG. hernete@ufla.br

2. Engenheiro Agrônomo, DS. Bioquímica, Professor do Departamento de Química/UFLA.

3. Bióloga, DS. Química Orgânica, Professora do Departamento de Química/UFLA.

4. Aluno do curso de Agronomia/UFLA.

5. Engenheiro Agrônomo, estudante de agrobioquímica, Departamento de Química/UFLA. 


\section{INTRODUCTION}

The coconut is a tree from tropical countries, originated and cultivated in the tropical zone and, preferentially, on the coast and in islands Coconut has several by products like sap, leaves, stem, roots and mainly its fruits, from which several products of domestic, commercial or industrial usage (Cortesão, 1956).

Cocos nucifera $\mathrm{L}$. is from Arecaceae family and Cocoineas tribe, it is a high stand palm tree, which can reach $20-30 \mathrm{~m}$ of height, the fruits are vulgarly known as "cocos", and they form a bunch or a composition of fruits in different stages of development.

The fruit contains, a bit before ripening, a whitish liquid, of sweet flavor. This liquid is a pleasant and refreshing dink, which is called "coconut water" and it is widely consumed in tropical countries. This water is flavorsome, sweet, slightly acid and very rich in phosphorus and potassium (Gomes, 1976).

The endosperm begins to form in the side of the fruit that is opposite to the peduncle as a gel, and spreads itself throughout the surface of the fruit. This formation starts when the coconut is about 5 to 6 months old and is due to the sweet solution, which is the coconut water. At 7 months, the endosperm develops in the entire inside of the fruit, and it is more consistent. At 10 months, the endosperm is completely ripe, and the endocarp or peel is dark and hard (Medina et al., 1980 e Maia e Castro, 1985).

Besides the growth substances, the coconut water has reducing sugars (glucose and laevulose) whose concentration reaches $5 \%$ when the water is fully formed (Coste, 1969).

The coconut water presents a series of nutritional and therapeutic properties, being a natural, acid and sterile solution, which contains mineral salts, sugars, vitamins, and proteins (Jayalekshmy et al., 1986), besides growth factors and neutral fats.

Pandolina (1983) has verified that carbohydrates are the main constituents of coconut water, and in the green coconut the greatest part is glucose and fructose, while sucrose is the main one in ripe coconuts.

Calvette et al. (2000) reported the huge growth of the coconut water consumption lately. The preference of the customer for this product is mainly due to its sensory qualities, but the great search is possibly related to the recovery of electrolytes, which is attributed to its balanced composition. The expansion of this market agrees with the possibility of drinking a health, natural and efficiently distributed refreshment. The usage of different technologies, including the sterile bottling, has expanded commercially, especially in regions where coconut is not produced, mainly because of the easy transportation and storage on shelf for long periods. The present research has evaluated the levels of total sugars, reducing sugars, sucrose, glucose, and fructose by calorimetric methods, of four coconut water brands, considering that 3 are long-life (tetra-pak bag) and one bottled, in the Biochemistry Laboratory of Universidade Federal de Lavras, aiming to evaluate the nutritional quality.

\section{MATERIAL AND METHODS}

\section{Material}

The bottled coconut water was bought in stores in Lavras, Minas Gerais, from February to Abril, 2001, and received the following designations: A, B, C, D and $\mathrm{E}$, and $\mathrm{E}$ was coconut water 'in natura' (control).

\section{Statistical analysis}

The statistical determinations were done using the completely randomized design, with 5 coconut water brands and 5 replicates, and they were performed in the SANEST software (Zonta e Machado, 1991).

\section{The methodologies of the chemical analyses by colorimetric methods were}

a) Extracted by Lane-Enyone methodology (AOAC, 1992) and determined by Somogy's technique, adapted by Nelson (1944). The readings were performed in VARIAN spectrophotometer, Cary 50, Simple reads software. In order to perform the measurements it was used $0,5 \mathrm{~mL}$ of extract without protein $(1: 100)$ to get the reducing sugars, and $1,0 \mathrm{~mL}$ of extract without protein for non-reducing sugars.

b) Anthrone methodology, cited by Dische (1962). Using Anthrone in $\mathrm{H}_{2} \mathrm{SO}_{4} 13,8 \mathrm{M}$ and addition of $\mathrm{KOH} 30 \%$, it was possible to calculate the level of fructose, analyzing the samples in VARIAN spectrophotometer, Cary 50, Simple reads software. The dilution of the coconut water was 1:100 and to get the contents of sugars, $200 \mathrm{iL}$ of the samples were used.

c) Glucose oxidase test - disaccharides to determine the contents of glucose of the samples, whose amounts used were 100iL (Dahlquist, 1968). 


\section{RESULTS AND DISCUSSION}

The average values of total sugars were 2,7 to $6,4 \mathrm{~g} / 100 \mathrm{~mL}$, with a significant difference, Tables 1 and 3; brand $\mathrm{A}$ had the highest $(6,4 \mathrm{~g} / 100 \mathrm{~mL})$, and $\mathrm{E}$ the lowest $(2,7 \mathrm{~g} / 100 \mathrm{~mL})$. There was a significant difference between the averages of reducing sugars from the evaluated brands, which varied from 0,62 to 4,92 $\mathrm{g} / 100 \mathrm{~mL}$, Tables 1 and 3. Brand B had the lowest level of reducing sugars $(0,62 \mathrm{~g} / 100 \mathrm{~mL})$, and brand A the highest $(4,97 \mathrm{~g} / \mathrm{mL})$, similar to the control (E). Maciel et al. (1992), studying a dwarf coconut from Pernambuco in the $7^{\text {th }}$ month of ripening, found $2,1 \mathrm{~g} / 100 \mathrm{~mL}$ for total sugars and $1,9 \mathrm{~g} / 100 \mathrm{~mL}$ for reducing sugars. Louis (1977) studying coconuts from India and yellow semigiant cultivar in the $6^{\text {th }}$ stage of maturation has obtained the present values of total sugars: $5,07 \mathrm{~g} / 100 \mathrm{~mL}$ and $6,19 \mathrm{~g} / 100 \mathrm{~mL}$, and the other 7 studied cultivars have remained between 4,36 to $6,2 \mathrm{~g} / 100 \mathrm{~mL}$. The level of non-reducing sugars varied considerably between cultivars, from 0,04 to $1,68 \mathrm{~g} / 100 \mathrm{~mL}$, and these results corroborate with the ones from this work, and it is possible to perceive that the levels vary amid the different brands.

Fructose varied from $0,2 \%$ to $1,9 \%$, brand A presenting the highest value $(1,9 \mathrm{~g} / 100 \mathrm{~mL})$ followed by the control $(\mathrm{E})$, and brand $\mathrm{D}$ had the lowest value $(0,24$ $\mathrm{g} / 100 \mathrm{~mL}$ ), with a significant difference (Tables 1 and 3 ). Glucose presented significant difference among the brands and varied from 0,4 to $2,3 \mathrm{~g} / 100 \mathrm{~mL}$., being the highest content observed in brand $\mathrm{E}(2,3 \mathrm{~g} / 100 \mathrm{~mL})$ and the lowest in brand $\mathrm{D}(0,4 \mathrm{~g} / 100 \mathrm{~mL})$. For sucrose, there was also a significant difference, in which the average values ranged from 1,5 to $3,7 \mathrm{~g} / 100 \mathrm{~mL}$ (Tables 1 and $4)$. Brand $B$ presented the greatest amount of sucrose $(3,7 \mathrm{~g} / 100 \mathrm{~mL})$ and $\mathrm{C}$ the smallest $(1,5 \mathrm{~g} / 100 \mathrm{~mL})$. Srebernich (1998) determined sucrose, fructose and glucose from the hybrid cultivar PB 121, which is the principal Brazilian material, and from the giant cultivar, naturally found on Brazilian beaches. The coconut water from different fruits, of different years and stages, from these cultivars had the values of fructose varying from the $6^{\text {th }}$ to the $10^{\text {th }}$ month from $3,07 \%$ to $0,40 \%$, the ones of glucose from $2,37 \%$ to $0,68 \%$, and of sucrose from $0,61 \%$ to $2,36 \%$, being these results compatible with the ones from this work, but with the levels of sucrose from brand $\mathrm{D}(3,53 \mathrm{~g} / 100 \mathrm{~mL})$ and $\mathrm{B}(3,69 \mathrm{~g} / \mathrm{mL})$ being beyond those limits, what is possibly due to adulteration, maybe because sucrose is a common and low cost sugar.

According to Tables 1 and 2, the average values of total sugars are compatible with the ones shown in the package.

TABLE 1 - Average values of the levels of sugars analyzed by SANEST.

\begin{tabular}{|c|c|c|c|c|c|}
\hline \multicolumn{2}{|c|}{ Total Sugars } & \multirow{2}{*}{$\begin{array}{l}\begin{array}{c}\text { Reducing } \\
\text { Sugars }\end{array} \\
\text { Somogy-Nelsor }\end{array}$} & \multirow[t]{2}{*}{ Sucrose } & \multirow{2}{*}{$\begin{array}{c}\text { Glucose } \\
\text { Got }\end{array}$} & \multirow{2}{*}{$\begin{array}{l}\text { Fructose } \\
\text { Anthrone }\end{array}$} \\
\hline Brand & & & & & \\
\hline A & 6,42 & 4,97 & 2,14 & 1,52 & 1,91 \\
\hline B & 4,51 & 0,62 & 3,69 & 0,42 & 0,36 \\
\hline $\mathrm{C}$ & 2,7 & 1,0 & 1,56 & 0,56 & 0,4 \\
\hline $\mathrm{D}$ & 4,97 & 1,25 & 3,53 & 0,4 & 0,24 \\
\hline $\mathrm{E}$ & 3,42 & 4,95 & 1,79 & 2,3 & 1,38 \\
\hline
\end{tabular}


TABLE 2 - Nutritional facts from $100 \mathrm{~mL}$ of coconut water (package information from A, B, C and D).

\begin{tabular}{lcccc}
\hline \multicolumn{1}{c}{ Content } & A & B & C & D \\
\hline Energy Kcal & 20 & 19 & - & 19 \\
\hline Proteins g & 0,1 & 0,1 & - & 0,1 \\
\hline Carbohydrates (g) & 5,5 & 5,0 & - & 5,0 \\
\hline Lipíds (g) & 0,05 & 0,05 & - & 0,05 \\
\hline
\end{tabular}

TABLE 3 - Summary of the ANOVAS of levels of total sugars, reducing and non-reducing, from brands A, $\mathrm{B}, \mathrm{C}, \mathrm{D}$ and $\mathrm{E}$ of coconut water.

\begin{tabular}{lccc}
\hline & \multicolumn{3}{c}{ Average Square } \\
\cline { 2 - 4 } $\begin{array}{l}\text { Causes of } \\
\text { variation }\end{array}$ & GL & $\begin{array}{c}\text { Total } \\
\text { sugars }\end{array}$ & $\begin{array}{c}\text { Reducing } \\
\text { sugars }\end{array}$ \\
\hline Brands & 4 & $12,9^{* *}$ & $23^{* *}$ \\
Error & 20 & 0,3 & 0,11 \\
\hline $\mathrm{CV}(\%)$ & & 11,73 & 13,17 \\
\hline
\end{tabular}

ns not significant at $5 \%$ by the $F$ test

*Significant at $5 \%$ by the $\mathbf{F}$ test

** Highly significant at $1 \%$ by the $\mathbf{F}$ test

TABLE 4 - Summary of the ANOVAS of levels of sucrose, fructose and glucose from brands A, B, C, D and E of coconut water.

\begin{tabular}{ccccc}
\hline \multirow{2}{*}{$\begin{array}{c}\text { Causes of } \\
\text { variation }\end{array}$} & \multicolumn{4}{c}{ Average Square } \\
\cline { 2 - 5 } & GL & Sucrose & Glucose & Fructose \\
\hline Brands & 4 & $6,5^{* *}$ & $3,5^{* *}$ & $2,7^{* *}$ \\
Error & 20 & 0,18 & 0,04 & 0,03 \\
\hline $\mathrm{CV}(\%)$ & & 16,61 & 19,96 & 20,21 \\
\hline
\end{tabular}

ns not significant at $5 \%$ by the $F$ test

*Significant at $5 \%$ by the $\mathbf{F}$ test

** Highly significant at $1 \%$ by the $\mathbf{F}$ test

\section{CONCLUSION}

Considering the sugar contents, brand A was significantly equal to $\mathrm{E}$ (control).
Only brands B and D presented extremely high sucrose level, what can indicate adulteration.

\section{BIBLIOGRAPHY}

ASSOCIATION OF OFFICIAL ANALYTICAL CHEMISTS. Official methods of analysis of the Association of Official Analytical Chemists. 22. ed. Arlington, 1992.

CALVETTE, Y.; SARMENTO, W. F.; ROSENTHAL, A.; FOGUEL, D.; SILVA, J. L. Caracterização preliminar da atividade da peroxidase da água de coco e de sua suceptibilidade à alta pressão. In: CONGRESSO BRASILEIRO DE CIÊNCIA E TECNOLOGIA DE ALIMENTOS, 17., 2000, Fortaleza. Resumo... Fortaleza: [s.n.], 2000.

CORTESÃO, M. Culturas tropicias: plantas oleaginosas. Porto: Clássica, 1956.

COSTE, R. El cocotero. Barcelona: Blume, 1969. (Coleccion Agricultura Tropical).

DISCHE, Z. General color reactions. In: WHISTLER, R. L.; WOLFRAM, M. L. (Eds.). Carbohydrate chemistry. New York: Academic, 1962. p. 477-512.

DAHLQUIST, A. Assay of intestinal dissacharidases. Analythical Biochemistry, New York, v. 22, p. 99-107, 1968.

GOMES, R. P. O coqueiro-da-Baía. 6. ed. São Paulo: Nobel, 1976.

JAYALEKSHMY, A.; ARUMUGHAN, C.; NARAYANAN, C. S.; MATHEW, A. G. Changes in the chemical composition of coconut water during maturation. Journal of Food Science and Tecnology, Oxford, v. 23, n. 4, p. 203-207, 1986.

LOUIS, I. H. A study on variation in tender nut characters in eight coconut varieties. Journal of Plantation Crops, Kasaragod, v. 5, n. 1, p. 59-60, 1977.

MACIEL, M. I.; OLIVEIRA S. L.; SILVA, I. P. da. Effects of different storage conditions on preservation of coconut (Cocos nucifera) water. Journal of food Processing and Preservation, Westport, v. 16, p. 13-22, 1992.

MAIA, G. A.; CASTRO, F. A. Coco: leite e coco ralado. Fortaleza: NUTEC, 1985. 48 p. (Série Informações Tecnológicas).

Ciênc. agrotec., Lavras. V.27, n.5, p.1063-1067, set./out., 2003 
MEDINA, J. C.; GARCIA, J. L. M.; MARTIN, Z. J. de; KATO, K.; TERUO, P.; TURATTI, J. M.; SANTOS, L. C. dos; SILVA, M. T. C.; CANTO, W. L. do; BICUDO NETO, L. C.; MORETTI, V. A. Coco: da cultura ao processamento e comercialização. Campinas: Instituto de Tecnologia de Alimentos, 1980. (Série Frutas Tropicais, 5).

NELSON, N. A. Photometric adaptation of Somogyi method for the determination of glucose. Journal of Biological Chemists, Baltimore, v. 153, n. 1, p. 375$380,1944$.
PANDOLINA, W. G. Coconut water and coconut sap: suggestion for research an development. Technician, [S.1.], v. 1, n. 2, p. 37-48, 1983.

SREBERNICH, S. M. Caracterização física e química da água do fruto de coco (Cocos nucífera), variedades gigante e híbrido PB-121, visando o desenvolvimento de uma bebida com características próximas da água de coco. 1998. Tese (Doutorado em Engenharia de Alimentos) - Universidade Estadual de Campinas, Campinas, 1998.

ZONTA, E. P.; MACHADO, A. A. Manual do sanest: sistema de análise estatística para microcomputadores. Pelotas: UFP, 1991. 102 p. 